DOI 10.37882/2500-3682.2022.01.07

\title{
ИСТОРИКО-ФИЛОСОФСКИЙ АНАЛИЗ ВЗАИМООТНОШЕНИЙ «ЧЕЛОВЕК-ТЕХНИКА-ОБЩЕСТВО»
}

\section{HISTORICAL AND PHILOSOPHICAL ANALYSIS OF RELATIONSHIP "MAN-TECHNOLOGY-SOCIETY"}

\section{N. Nekrasova \\ S. Nekrasov \\ V. Klepatsky}

Summary: The article examines the main problems of the relationship between philosophy, technology, man at various stages of the development of technology in European and Russian philosophical thought. Particular attention is paid to the negative consequences of the development of technology, its impact on nature and humans. The influence of the global information network on the harmful processes occurring in the minds of young people and the impact of modern means of information technologies on its psychological, emotional and moral motivation, which leads to a gradual loss of a person of his true essence, is analyzed.

Keywords: information technology society, information communications, manipulation of consciousness, basic modes of brain operation, neural networks, human thinking, motivation.

\author{
Некрасова Нина Андреевна \\ Д.ф.н., профессор, Российский университет транспорта \\ (МИИТ), г. Москва \\ sinekrasov@mail.ru \\ Некрасов Сергей Иванович \\ Д.ф.н., профессор Московский государственный \\ университет гражданской авиации \\ sinekrasov@mail.ru \\ Клепацкий Владислав Владимирович \\ К.ф.н., дочент, Российский университет транспорта \\ (МИИТ), г. Москва \\ vlad_kl@mail.ru
}

Аннотация: В статье рассматриваются основные проблемы соотношения философии, техники, человека на различных этапах развития техники в европейской и отечественной философской мысли. Особое внимание уделяется негативным последствиям развития техники, её влияние на природу и человека. Анализируется влияние глобальной информационной сети на пагубные процессы, происходящие в сознании молодёжи, и воздействие современных средств информационных технологий на её психологическую, эмоциональную и нравственную мотивацию, что ведёт к постепенной потере человеком своей подлинной сущности.

Ключевые слова: информационно-техническое общество, информационные коммуникации, манипуляция сознанием, базовые режимы работы мозга, нейронные сети, мышление человека, мотивация.

научно-технического знания.

Своими корнями история техники уходит в глубокую древность. В античности понятие «techne» было синонимом мастерства в любой сфере деятельности - охоте, ремесле, искусстве, врачевании и т.п. Аристотель в «Никомаховой этике» различал понятия «techne», «emperiaria» (опытное), «еріsteme» (теоретическое) знание. Техника рассматривалась как такая область знаний, которая связана с деятельностью человека, то есть с тем, что создано или будет создано, чтобы служить человеку.

Со временем менялось содержание этого понятия, а с научно-техническим прогрессом расширялось и его предметное поле, включая в него как неорганическую, так и органическую природу.

В конце XIX в. возник огромный интерес к теоретическим проблемам техники, что повлекло за собой интерес к философскому осмыслению феномена «техника». В результате этого - к рождению понятия «философия техники», а основателем этого философского направления стал немецкий философ Э. Капп, который изложил свои взгляды на проблемы техники в своей работе «К истории 
возникновения культуры с новой точки зрения», изданной в 1877 г.

В это же время русский инженер П.К. Энгельмейер опубликовал свой труд «Философия техники». Но только к началу XX в. возникает устойчивый интерес к этой проблеме, а в 60-е годы философия техники обретает статус самостоятельной научной дисциплины. Осмысление места и сущности техники в обществе, особенности её развития и значения для будущего человеческой цивилизации стало её задачей, а основной её проблемой - анализ различных моделей взаимоотношений «человек-природа». А также в круг её проблем вошли: формирование новой системы ценностей на основе отношений человека с природой, выработки у него «технического поведения», осмысления им пределов технического развития.

Взаимоотношения человека с техникой всегда были актуальной темой. Само возникновение техники связано с существованием человека, а её использование осуществляется в процессе всей нашей жизни. Традиционно представления о необходимости техники, её сущности и предназначении в обществе основаны на признании, что она повышает эффективность труда, сохраняет здоровье человеку и облегчает ему жизнь [5, с. 1570].

Но понимание техники как совокупности средств человеческой жизнедеятельности, которые предназначены осуществлять процессы производства и обслуживать непроизводственные потребности человека и общества, то есть узкотехнического, инструментального явления давно ушло в прошлое. Сегодня техника уже не рассматривается как средство, которое только усиливает природные возможности человека. Предметное поле техники сегодня включает в себя не только знания, но и сферу человеческой деятельности, которая существенно изменяет окружающий мир, природную среду, мастерство человека, его сознания, восприятия им мира, всей системы ценностей. Техника привела к необратимым изменениям среду обитания, отодвинув на задний план живую природу. Господство техники обусловило рационализацию мира, и стандартизацию поведения человека, создало условия для манипуляции его сознанием.

Ещё в начале XX в. русские философы и писатели Н.A. Бердяев, Ф.М. Достоевский, В.В. Розанов и другие тревожно оценивали негативные следствия техники. Так Н.А. Бердяев, отмечая парадоксальность техники, писал: ««...без техники невозможна культура, с нею связано само возникновение культуры, и окончательная победа техники в культуре, вступление в техническую эпоху влечёт культуру к гибели» [4, с. 149]. А В.В. Розанов, отмечая негативные следствия техники, писал: «техника, присоединившись к душе, дала ей всемогущество. Но она же её и раздавила. Появилась «техническая» душа....и вдохновение умерло» [2, с. 223].
Анализ влияния техники на человека и общество делали представители разных западно-европейских философских направлений. Глубокую антропологическую трактовку техники дал Х. Ортега-и-Гассет. Хотя техника призвана преобразовывать природу, удовлетворяя человеческие потребности, но этим она не должна ограничиваться, отмечает философ. Она призвана снижать физические затраты человека по овладению силами природы. Он пишет: ««...и смысл, и причина! техники лежат за её пределами, а именно, в использовании человеком его избыточных, высвобожденных благодаря этой самой технике сил. Такова миссия техники - освобождение человека, дарующее ему возможность быть самим собой» $[3$, с. 47, 36]. Задача техники, по его мнению, освободить человека от слияния с природой и перенести его на машинный мир.

Иначе оценивал технику М. Хайдеггер, утверждая, что она является разновидностью творчества человека, но в техническом воплощении: «Техника - вид раскрытия потаённости. Сущность техники расположена в области, где имеют место открытие и его непотаённость, где сбывается... истина» [6, с. 325]. Сущностью техники М. Хайдеггер считал «обнаружение бытия и выявление «потаённого. Современная техника, по его мнению, формирует «технический» способ конструирования мифа, где изменяются связи техники - человека - природы. Природа превращается в материал и источник добывания энергии. Человек становится результатом опредмечивания и моментом развития технических средств. Наяву проявляется отчуждение форм существования человека.

Современный мир порождает иные области взаимодействия человека с техникой, которые отражают сущностные характеристики человека, что вызывает многочисленные дискуссии.

XXI век можно определить, как время биотехнологической революции, так как биология демонстрирует огромные достижения и технические возможности. Возникают предпосылки воздействия на человека, вплоть до генетической его коррекции. Такие способы влияния науки на глубины человеческого существования вызывает негативные реакции общества. Конечно, некоторые результаты такого вмешательства можно оправдать, но большая часть из них крайне нежелательна. [7, с. 17-18].

Воздействие на человека на молекулярно-генетическом уровне связано с высокими технологиями. Но такой технологический подход конструирования человека, когда люди становятся объектом генетических манипуляций, не может не вызывать негативных реакций общества. Подобные воздействия на человека связаны с разнородными рисками и затрагивают права человека. Недаром К. Ясперс, определяя назначение техники, утверждал, что её власть над природой «обретает смысл 
лишь при наличии целей, поставленных человеком» [8, с. 117,118$]$. А в подобных случаях происходит искажение истинных целей человека.

В современном информационно-техническом мире вопросы морали становятся особенно актуальными. Когда человек всё более зависит от власти техники, нравственный статус техники становится очень острым. Человек теряет свою свободу. И здесь возникает вопрос о необходимости осуществления новаторских технологических проектов (типа планирования человека). Конечно, на сам процесс поиска нравственный запрет наложить нельзя, так как наука обладает правом исследовать любую сферу окружающей среды. Но главная составляющая возможностей науки - моральная ответственность не науки и техники, а учёных и техников, то есть тех, кто создаёт и применяет её, выступает на передний план.

Ответственность, как пишет Э. Агацци, ««...предлагает свободу (ибо только свободные существа могут быть ответственными) и в то же время признает ограничения свободы, накладываемые долгом, то есть уважение к требованиям и моральным ценностям, которые не ограничивают свободу, но внутренне обязывают к ее ограничению» [1, с. 284].

Применение техники связано с риском. При этом риск удачи и риск неудачи предусмотреть нельзя. Но ответственность и учёных, и инженеров в любом случае несут оба создателя за любой вариант риска. Независимо от профессионализма их совместная ответственность рассматривается через призму общечеловеческой морали.

В современном мире особое место отводится компьютерной технике и информационным технологиям, которые существенно изменили качество жизни как человека, так и общества. Глобальные информационные сети, электронные способы обработки и хранения информации, создание широкой системы управления, возможность одновременного существования в реальной и виртуальной реальности - эти технологические инновации становятся неотъемлемой частью современной культуры. Без внедрения этих инноваций наше общество было отлучено от мировых информационных процессов. Эти новые средства информационных коммуникаций создают возможность каждому человеку быть психологически сопричастным к мировым процессам, при этом, не участвуя в них. Развитие информационной коммуникативности способствует научным, экономическим, культурным и другим международным связям, что значительно изменяет качество жизни современного человека и общества в целом.

Однако, развитие информационных технологий имеет и негативные последствия, связанные с деградацией человека и его мозгом и сознанием.
Если ранее исследователи мозга человека считали, что мозг человека организован по локальному принципу - разделён на отдельные зоны, а каждая зона (слуховая, кора, зрительная кора и др.) отвечает за свою функцию, то сегодня учёные пришли к выводу: мозг человека устроен значительно сложнее. До 25 лет жизни связи мозговых зон имеют локализацию, что необходимо для выработки концентрации внимания и развития потенциально заложенной в человеке способности ориентироваться в конкретной ситуации. Первые 25 лет жизни это период программирования мозговой деятельности (так называемого «программного сервера»). В это время нейронные клетки разных отделов мозга постепенно связываются друг с другом, формируя нейронные связи, то есть образуют нейронные сети, которые будут отвечать за базовые режимы работы мозга [9].

Группа американских учёных под руководством профессора М. Рейчела, исследуя работу мозга человека, выделили в нём два базовых режима и соответствующие им нейронные сети. Первая - дефолт система мозга осуществляет пассивный режим его работы (именно здесь рождаются творческие решения, а самые ценные идеи инсайт), вторая - исполнительная система - отвечает за оперативность решения задач [10], которая активируется в момент потребления информации, что проявляется в мобилизации и концентрации внимания (как бы «забывая себя» и входя в поток информации).

Дефолт система мозга (то есть сеть пассивного режима работы мозга) - это та нейронная сеть, которая активизируется тогда, когда человек «погружается в себя», то есть, не связан с внешним миром и не занят решением задачи. Именно в это время внешнего бездействия приходят самые интересные идеи: мозг человека погружается в интеллектуальные объекты, выстраивая внутренние отношения между ними в разных ситуациях, анализируя варианты этих отношений. Эти процессы осуществляются в состоянии покоя (то есть внешнего бездействия) мозга.

Эти два режима мозга (сеть оперативного решения проблемы и сеть пассивного режима работы - дефолт систем мозга) действуют в противоположных фазах: если активна одна система, то вторая отключается, и наоборот. Другими словами, обе системы являются антагонистическими в своём внешнем проявлении.

Наше время - это время получения избыточной информации, когда сеть оперативного решения задач постоянно активна, а в зону дефолт системы мозга энергия практически не поступает. Эта зона перестаёт активно работать (мозг человека как бы «впадает в спячку», то есть перестаёт думать и творить).

Как отмечают учёные, современные дети (к 14-17 го- 
дам) 60-70\% времени активно потребляют информацию, отправляя дефолт систему (то есть свой сервер мышления) в спячку, а значит, он перестаёт формироваться. Чтобы сервер мышления переключился в нужный режим (стал думать) необходимо время. А если этого времени нет, то мозг продолжает находиться в сети оперативного решения задач. Так происходит деформация мозговой деятельности человека.

Другая проблема современного гипер-информационного общества связана с разрушением социальными отношениями, так как в процессе эволюции дефолт систем мозга сформировалась как социальная система для того, чтобы человек выстраивал социальные отношения с другими людьми в процессе их общения. Но сегодня реальное общение людей сокращается до минимума, что учёные называют «эпидемией цифрового аутизма» (суть которого заключается в том, что молодёжь не может осуществлять деятельный психологический контакт с другими). Так, ценность другого реального человека, интерес к его взглядам, ценностям (к его внутреннему миру) заменяется контактом с искусственным субъектом (компьютером). Человек постепенно теряет свою сущность, которая проявляет себя только в общении с другим реальным человеком.

Кроме этого, если дефолт система мозга не работает, человек утрачивает способность к мотивации и прогнозированию будущего, а значит - теряет желание к обучению. При этом возрастает возможность к манипуляции сознанием человека через глобальные коммуникативные сети.
Цифровая зависимость человека ведёт и к эмоциональным реакциям: получение информации превращается в получение удовольствия. Чем быстрее и легче человек получает информацию, тем быстрее он получает удовольствие. Если же получение удовольствия затягивается, то человек становится агрессивным, вплоть до тенденции к суициду.

Чтобы дефолт система мозга работала, необходимо ограничивать потребление информации и увеличивать количество социальных коммуникаций и коллективных форм познавательного процесса путём диалоговых форм сотрудничества.

На основании анализа негативных последствий влияния информационных технологий на развитие мышления человека и деградации его социальных отношений можно утверждать, что в процессе информатизации общества огромную роль приобретает система образования, которая включает в себя как базовое образование в школе, так и профессиональное научное образование в ВУЗах, так как человеческий интеллектуальный потенциал является главной ценностью и национальным богатством страны.

Таким образом, технологические риски приобретают опасный характер. Только руководствуясь нравственным императивом, возможно ослабить всё усиливающиеся технократические тенденции современного мирового сообщества, формируя предпосылки для утверждения гуманистических ценностей в обществе и реализации творческого потенциала человека.

\section{ЛИТЕРАТУРА}

1. Агацци Э. Моральное измерение науки и технике. М.: Московский философский фонд, 1998. 344 с.

2. Бердяев Н.А. Человек и машина (Проблема социологии и метафизики техники) // Вопросы философии, 1989. №2. С. 150-168.

3. Ортега-и-Гассет Х. Размышление о технике. М.: Прогресс, 2000. С.164-232

4. Розанов В.В. Мысли о литературе. М: Современник, 1989, 608 с.

5. Российский энциклопедический словарь. В 2 кн. М.: Большая Российская энциклопедия, 2001, Кн. 2: Н-Я. - 2015 с.

6. Хайдеггер М. Время и бытие,- М.: Республика, 1993. - 445 с.

7. Юдин Б.Г. О человеке, его природе и его будущем // Вопросы философии, 2004. №2. С. 16-28.

8. Ясперс К. Смысл и назначение истории. М.: Политиздат, 1991. 527 с.

9. Raichle M.E., MacLeod A.M., Snyder A.Z., Powers W.J., Gusnard D.A., Shulman G.L. A default mode of brain function. Proceedings of the National Academy of Sciences of the United States of America. 2001. P. 676-682.

10. Linda Patia. Adolescent Neurodevelopment, Journal of Adolescent Health 52 (2013) S7-S13). https://www.iahonline.org/action/showPdl7piCS1054-139X\%281 $2 \% 2900207-8$

( ) Некрасова Нина Андреевна (sinekrasov@mail.ru), Некрасов Сергей Иванович (sinekrasov@mail.ru), Клепацкий Владислав Владимирович (vlad_kl@mail.ru).

Журнал «Современная наука: актуальные проблемы теории и практики» 